Anna Falana-Jafra

DOI: 10.33896/PorJ.2021.10.4

(Uniwersytet Humanistyczno-Przyrodniczy im. Jana Długosza,

Częstochowa,

e-mail: anna.falanajafra@gmail.com)

ORCID: 0000-0002-9901-1791

\title{
MILCZENIE JAKO PERFORMATYWNY AKT PRZESTĘPCZY \\ NA PRZYKLADZIE POLSKIEGO KODEKSU KARNEGO
}

\section{WSTĘP}

Prezentowane poniżej wyniki badań mają charakter interdyscyplinarny, opierają się zarówno na metodologii językoznawczej (teoria aktów mowy Johna L. Austina), jak i prawnej (teoria przestępstw i ich klasyfikacje). Ich celem jest udzielenie odpowiedzi na pytanie, czy przestępczy akt mowy polegający na milczeniu ma charakter performatywny, a więc czy wywołuje analogiczne do aktów zwerbalizowanych skutki na płaszczyźnie prawnokarnej. Autorka stawia hipotezę, zgodnie $z$ która tak właśnie jest, a następnie poddaje ja weryfikacji $\mathrm{w}$ świetle wymienionych teorii naukowych. Milczenie rozumiane jest jako powstrzymanie się od artykulacji bądź zapisu wówczas, gdy prawo ich od podmiotu wymaga. Zaproponowane typologie przestępstw $z$ milczenia maja charakter wstępny i autorski; nie stanowią rozłącznych klasyfikacji $z$ uwagi na obiektywną niemożność ich utworzenia, wynikająca $z$ prawno-językowej konstrukcji poszczególnych przestępstw.

\section{ZAGADNIENIE PERFORMATYWNYCH AKTÓW MOWY W ŚWIETLE TEORII PRZESTĘPSTW}

Badania języka prowadzone w ujęciu pragmatycznym opierają się między innymi na teorii aktów mowy zaproponowanej przez Johna L. Austina, zgodnie z która - poza wypowiedziami opisującymi rzeczywistość - wyróżnić można wypowiedzi, które per se tę rzeczywistość kreują. Pierwsze $z$ nich J.L. Austin określił mianem zdań konstatujących, a drugie - zdań performatywnych [1962]. Te ostatnie nie mogą być rozpatrywane w kategoriach prawdy i fałszu, sa bowiem w istocie „wykonaniem jakiejś czynności, (...) czymś, o czym nie myśli się normalnie jak tylko o powiedzeniu czegoś" [Austin 1993, 555]. Performatywnym aktom mowy przeważnie towarzyszyć musza ściśle określne przez konwencję 
społeczną okoliczności, które wespół z wypowiadanymi słowami przekształcaja stany zastane w stany docelowe. Do wywołania oczekiwanych zmian w świecie konieczne jest zatem równoległe zaistnienie tak zwanych warunków fortunności:

\begin{abstract}
Wypowiedź bynajmniej nie jest zazwyczaj, jeżeli w ogóle jest, jedyną rzeczą konieczna, by uznać czynność za wykonana. Mówiąc ogólnie, zawsze konieczne jest, by okoliczności, w jakich wypowiada się słowa, były na jakiś sposób czy na jakieś sposoby odpowiednie, a bardzo często konieczne jest, by bądź sam mówiący, bądź inne osoby wykonywali również pewne inne działanie „fizyczne” lub „umysłowe”, czy nawet czynności wypowiadania dalszych słów [Austin 1993, s. 14-15].
\end{abstract}

Teoria Austina doskonale charakteryzuje rozliczne działania podejmowane na płaszczyźnie prawnej. To właśnie w tej sferze społecznych aktywności wypowiedzi o charakterze performatywnym sa wyposażone w szczególnego rodzaju moc sprawcza. Poprzez słowa, przy spełnieniu wymaganych prawem warunków towarzyszących, dochodzi bowiem do wywoływania skutków istotnie ingerujących w życie jednostek i grup. Działania w sferze prawnej podejmowane sa przez podmioty wyposażone przez ustawodawcę $\mathrm{w}$ odpowiednie kompetencje sprawcze; przeważnie sa to osoby piastujące funkcje związane ze ściganiem przestępstw i wymierzaniem sprawiedliwości (prokuratorzy, sędziowie), funkcje obrończe (adwokaci) czy funkcje związane $z$ dokonywaniem rozmaitych czynności prawnych (notariusze, radcowie prawni, pełnomocnicy). Często w uprawnienia sprawcze prawodawca wyposaża także samych obywateli, traktowanych w państwie demokratycznym jako podmioty, a nie jako przedmioty prawa [Załucki i in. 2020]. Dzięki temu możliwe jest na przykład zawieranie umów, zawieranie małżeństw czy sporządzanie testamentów przez zainteresowane tym jednostki. Skutki wywoływane przez performatywne akty mowy maja w tym obszarze charakter konsekwencji prawnych, a więc powodują następstwa ściśle określone poprzez obowiazujace akty prawne. Usunięcie tych następstw przeważnie wiąze się z koniecznościa podjęcia kolejnych prawnie sformalizowanych działań, w tym także dokonania kolejnych językowych aktów mowy o charakterze performatywnym.

Jak się wydaje, silne sperformatyzowanie przestrzeni prawnej ukierunkowane jest w szczególności na zapewnienie pewności obrotu gospodarczego i względnej stałości osobniczych sytuacji prawnych. Realizacja tych wartości przyczynia się bowiem do budowania równowagi społecznej i harmonii działań podejmowanych zarówno przez obywateli, jak i przez organa państwowe.

Pomimo licznych badań językoznawczych nad performatywnymi aktami mowy w szeroko rozumianej przestrzeni prawnej stosunkowo mało uwagi poświęcono dotychczas przepisom sankcjonującym karnie określone wypowiedzi. Chodzi mianowicie o kategorię przestępstw lingwistycznych, których czynności sprawcze polegają na wyartykułowaniu 
bądź naniesieniu na zewnętrzny nośnik informacji określonych słów (na przykład przestępstwa lingwistyczne zniewagi, zniesławienia, doprowadzenia innej osoby do targnięcia się na własne życie, składania fałszywych zeznań, nękania, gróźb karalnych czy publicznego nawoływania do popełnienia zbrodni bąź występku). Wbrew pozorom odpowiedzialność karna przewidziana za działania stricte językowe nie należy do rzadkości - przestępstwa lingwistyczne penalizowane sa w niemal każdym rozdziale części szczególnej aktualnie obowiązującego w Polsce Kodeksu karnego. ${ }^{1}$ W ustawie tej - przez wzgląd na zasady spójnej i zwartej techniki prawodawczej - wypowiedzi performatywne mające charakter przestępczy nie zostały wymienione w sposób enumeratywny, lecz generalny. Przyjrzyjmy się kilku przykładom:

Kto pomawia inną osobę, grupę osób, instytucję, osobę prawną lub jednostkę organizacyjną niemającą osobowości prawnej o takie postępowanie lub właściwości, które moga poniżyć ja w opinii publicznej lub narazić na utratę zaufania potrzebnego dla danego stanowiska, zawodu lub rodzaju działalności, podlega grzywnie albo karze ograniczenia wolności. ${ }^{2}$

Kto przemoca lub groźbą bezprawną wywiera wpływ na czynności urzędowe organu administracji rządowej, innego organu państwowego lub samorządu terytorialnego, podlega karze pozbawienia wolności do lat $3 .^{3}$

Kto stosuje przemoc wobec osoby lub groźbę bezprawną w celu zmuszenia innej osoby do określonego działania, zaniechania lub znoszenia, podlega karze pozbawienia wolności do lat $3 .^{4}$

Kto wiedząc, że zagrożenie nie istnieje, zawiadamia o zdarzeniu, które zagraża życiu lub zdrowiu wielu osób lub mieniu w znacznych rozmiarach lub stwarza sytuację, mająca wywołać przekonanie o istnieniu takiego zagrożenia, czym wywołuje czynność instytucji użyteczności publicznej lub organu ochrony bezpieczeństwa, porządku publicznego lub zdrowia mająca na celu uchylenie zagrożenia, podlega karze pozbawienia wolności od 6 miesięcy do lat $8 .{ }^{5}$

O tym, które konkretnie wyrażenia uznane zostana za naruszające prawo, każdorazowo decyduja w polskim systemie prawnym niezależne i niezawisłe sady [Zubik 2020]. To do nich, w ramach tak zwanego sędziowskiego uznania, należy ocena, czy dana wypowiedź podlegała bę-

1 Ustawa z dnia 6 czerwca 1997 roku Kodeks karny, Dz. U. Nr 88, poz. 553 z późniejszymi zmianami.

2 Art. 212 par. 1 ustawy z dnia 6 czerwca 1997 roku Kodeks karny, Dz. U. $\mathrm{Nr} 88$, poz. 553 z późniejszymi zmianami.

3 Art. 224 par. 1 ustawy z dnia 6 czerwca 1997 roku Kodeks karny, Dz. U. Nr 88, poz. 553 z późniejszymi zmianami.

4 Art. 191 par. 1 ustawy z dnia 6 czerwca 1997 roku Kodeks karny, Dz. U. $\mathrm{Nr} 88$, poz. 553 z późniejszymi zmianami.

5 Art. 224a ustawy z dnia 6 czerwca 1997 roku Kodeks karny, Dz. U. Nr 88, poz. 553 z późniejszymi zmianami. 
dzie subsumcji pod norme prawna, a w konsekwencji - czy zostanie uruchomiona machina sankcji państwowych względem autora przestępczego aktu mowy. W tym kontekście uwagę zwraca fakt, iż przestępcze wypowiedzi performatywne pociagaja za soba sankcje prawnokarne. Polski Kodeks karny dzieli je na kary oraz środki karne, których celem jest nie tylko sprawiedliwa odpłata przestępcy, ale także przyszłościowe przysposobienie go do kultury prawnej oraz prewencja względem pozostałych członków społeczeństwa [Warylewski 2020].

$\mathrm{W}$ nauce prawa administracyjnego milczenie uznawane jest za akt zbliżony w swych funkcjach do wypowiedzi, choć ze swej natury niezwerbalizowany [por. Dobosz 2011]. Czy analogiczny status milczenie ma $\mathrm{w}$ przestrzeni prawnokarnej? By udzielić odpowiedzi na to pytanie, konieczne jest uprzednie skonstatowanie, jak rozumiane jest przestępstwo we współczesnej nauce prawa karnego. Legalna, choć niepełna definicja przestępstwa może zostać odkodowana $z$ treści art. 1. Kodeksu karnego, który wprowadza następujące warunki odpowiedzialności karnej:

Odpowiedzialności karnej podlega ten tylko, kto popełnia czyn zabroniony pod groźba kary przez ustawę obowiazująca w czasie jego popełnienia. Nie stanowi przestępstwa czyn zabroniony, którego społeczna szkodliwość jest znikoma. Nie popełnia przestępstwa sprawca czynu zabronionego, jeżeli nie można mu przypisać winy w czasie czynu. ${ }^{6}$

Koniecznymi elementami przestępstwa sa zatem wina sprawcy oraz odpowiednio wysoki stopień społecznej szkodliwości popełnionego przez niego czynu [Stefański i in. 2020]. Przestępstwo stanowi formę czynu zabronionego, ale nie jest $z$ nim tożsame. Możliwa jest bowiem sytuacja, w której sprawca wprawdzie realizuje określona przez przepisy prawnokarne czynność sprawcza, jednak nie ponosi za to winy (na przykład podejmujacc działania w stanie niepoczytalności). Należy ponadto zwrócić uwagę, iż w powszechnym języku polskim termin czyn wiąże się $z$ konotacjami aktywnościowymi, o czym świadcza jego definicje słownikowe: „to coś, co ktoś zrobił lub ma zrobić (...) jeśli wprowadzamy lub wcielamy słowa, myśli, idee itp. w czyn, to realizujemy je" [por. Bańko i in. 2007, s. 289-290]. W językowym obrazie świata Polaków najpewniej więc za czyn nie zostałoby uznane samo powstrzymanie się od działania [Bartmiński 2012]. Obecnie obowiazujący Kodeks karny posługuje się jednak odmienna, specjalistyczna kategoryzacja - zna i rozróżnia zarówno przestępstwa $z$ działania, jak i z zaniechania. Czyn ludzki polegać może na obu tych formach sprawczych (na przykład zabicie człowieka poprzez podanie mu trucizny albo poprzez niepodanie koniecznych do podtrzymania życia leków), a więcej - zdarza się, że ustawodawca konstruuje niektóre typy przestępstw w ten sposób, że wyklucza ontyczna możliwość

6 Art. 1. ustawy z dnia 6 czerwca 1997 roku Kodeks karny, Dz. U. Nr 88, poz. 553 z późniejszymi zmianami. 
ich popełnienia poprzez działanie (na przykład nieudzielenie pomocy osobie znajdujaccej się w stanie bezpośredniego zagrożenia zdrowia lub życia, ze swej istoty polegające na powstrzymaniu się od podejmowania działań ratowniczych).

Zaakcentować należy ponownie, iż milczenie jako przestępcza czynność performatywna wymagałoby zaistnienia określonego kontekstu swojej fortunności. Warto raz jeszcze nawiązać do słów J.L. Austina, który wymienia następujące ogólne warunki fortunności:

\footnotetext{
Musi istnieć pewna akceptowalna konwencjonalnie procedura, mająca pewien konwencjonalny efekt; procedura obejmująca wypowiedzenie pewnych słów przez pewne osoby w pewnych okolicznościach. W danym przypadku poszczególne osoby i okoliczności muszą być odpowiednie do wygłoszenia danej wypowiedzi. Procedura musi zostać wykonana przez wszystkich uczestników zarówno w sposób prawidłowy, jak i (...) kompletny. Jeśli procedura jest przeznaczona dla osób żywiących pewne myśli lub uczucia, lub też gdy ma ona zapoczątkować pewne zachowanie któregoś $z$ jej uczestników, wówczas biorąca w niej udział osoba musi faktycznie żywić te myśli lub uczucia, a uczestnicy muszą chcieć się zachować w ten sposób, oraz muszą się rzeczywiście w ten sposób zachować [1993].
}

J.L. Austin odnosi się wprawdzie do werbalnych aktów mowy, jednak jest oczywiste, że analogicznych warunków poszukiwać należy dla doniosłego prawnie milczenia. Kolejnym krokiem badawczym powinno być więc uważne prześledzenie treści obowiąujących przepisów, a także - o ile okaże się to możliwe - podjęcie próby utworzenia typologii przestępstw, które w dalszych rozważaniach określane będa mianem przestępstw $z$ milczenia.

\section{PRZYKLADY I WSTEPNE TYPOLOGIE TZW. PRZESTĘPSTW Z MILCZENIA}

Analiza części szczególnej Kodeksu karnego [art. 117. - art. 316.] umożliwiła zidentyfikowanie przestępstw, których czynności wykonawcze polegaja na zaniechaniu użycia języka. Znajduja się one między innymi w następujących rozdziałach części szczególnej ustawy karnej:

- w rozdziale XVII, zatytułowanym Przestepstwa przeciwko Rzeczypospolitej Polskiej,

- w rozdziale XXVII, zatytułowanym Przestępstwa przeciwko czci i nietykalności cielesnej,

- w rozdziale XXVIII, zatytułowanym Przestępstwa przeciwko prawom osób wykonujacym prace zarobkowa,

- w rozdziale XXX, zatytułowanym Przestepstwa przeciwko wymiarowi sprawiedliwości,

- w rozdziale XXXVI, noszacym tytuł Przestepstwa przeciwko obrotowi gospodarczemu i interesom majatkowym w obrocie cywilnoprawnym, 
- w rozdziale XXXVII, noszacym tytuł Przestępstwa przeciwko obrotowi pieniędzmi i papierami wartościowymi.

Przestępstwa $z$ milczenia godzą $\mathrm{w}$ różnorodne dobra chronione prawem - od dóbr indywidualnych, takich jak godność osobista, aż po dobra ogólnospołeczne, takie jak pewność obrotu gospodarczego. Dla każdego $z$ nich ustawodawca sformułował odmienne warunki fortunności, które $\mathrm{w}$ nauce prawa karnego materialnego określane sa mianem podmiotowych i przedmiotowych znamion czynu. Chodzi o szczególne okoliczności, których zaistnienie stanowi warunek konieczny do przypisania sprawcy odpowiedzialności karnej. Może to być kontekst sytuacyjny (na przykład składanie zeznań w charakterze świadka), fakt posiadania wiedzy na określony temat (na przykład niezawiadomienie organów ścigania o popełnieniu ciężkiego przestępstwa przez inną osobę) etc. Samo ujawnienie się tych okoliczności nie jest wystarczające - towarzyszyć im zawsze musi czyn sprawcy wyrażający się poprzez milczenie.

Przestępstwa $z$ milczenia penalizowane w polskim Kodeksie karnym - pomimo dzielących je różnic - maja pewne wspólne cechy charakterystyczne. Pierwszą $z$ nich jest swoistość czynności wykonawczej, która polega na powstrzymaniu się od użycia języka mówionego bądź pisanego. Sprawca musi więc być zdolny fizycznie i psychicznie do popełnienia przestępstwa $z$ milczenia, a więc musi posługiwać się językiem, potrafić rozpoznawać znaczenie swoich zachowań oraz świadomie kierować swoim postępowaniem (polskie prawo karne ustanawia granicę siedemnastego roku życia dla ponoszenia odpowiedzialności karnej). W razie niespełnienia któregokolwiek $z$ tych warunków nie będzie możliwe, co sygnalizowano już wyżej, przypisanie mu winy, która ma charakter zindywidualizowany. Warunek posługiwania się językiem obejmuje, jak się wydaje, nie tylko użytkowanie języka rodzimego (polskiego), ale także języków obcych czy niewerbalnych (np. język migowy). Osoby głuchonieme $i$ inne osoby niezdolne do posługiwania się językiem powszechnym nie sa a propri wyłączone $z$ zakresu potencjalnych sprawców przestępstw $z$ milczenia. Przykładowo, język migowy i odpowiadający mu tzw. alfabet palcowy są narzędziami w pełni zdatnymi do komunikowania się, w związku $z$ czym zaniechanie ich użycia należy traktować na równi z zaniechaniem ustnej bądź pisemnej wypowiedzi w języku powszechnym. Zaakcentować należy, że na organach ścigania i wymiaru sprawiedliwości ciąży obowiązek zagwarantowania osobom potrzebujacym pomocy tłumacza [Świecki $\mathrm{i}$ in. 2020]. Osoby takie same również powinny podjąć niezbędne starania o możliwość skorzystania $z$ takiej pomocy. O wyłączeniu odpowiedzialności za popełnienie przestępstwa $z$ milczenia można zasadnie mówić wyłącznie wobec osoby, która nie potrafi posługiwać się żadnym językiem symbolicznym rozumianym jako system znaków zdatnych do informowania i odbierania informacji od innych osób.

Kolejną cechą wspólna przestępstw $z$ milczenia jest bez wątpienia ich temporalność. Ze swej natury milczenie ma charakter procesowy, trwa 
określony czas, nie jest możliwe milczenie „jedno-” i „wielokrotne”. Nie należy mylić milczenia $z$ przerwami w mówieniu, które służą najczęściej uporządkowaniu myśli bądź zaczerpnięciu oddechu. Milczenie może występować w tle wypowiedzi, niejako jej towarzyszyć - na przykład przy przestępstwie zatajania prawdy w trakcie składania zeznan - jednak zawsze rozwija się ono w czasie i trwa dopóty, dopóki sprawca nie zdecyduje się wyartykułować wymaganej od niego przez system prawny wypowiedzi. Nie chodzi przy tym o jakakkolwiek wypowiedź, lecz o wypowiedź pozostająca $\mathrm{w}$ korelacji $z$ innymi warunkami fortunności przewidzianymi przez ustawodawcę dla wyłączenia negatywnych skutków związanych $z$ popełnieniem danego przestępstwa (na przykład złożenie zeznań odpowiadających prawdzie, mimo uprzednich kłamstw w charakterze świadka).

Właściwością charakterystyczna dla przestępstw $z$ milczenia jest ich różnorodna konstrukcja ontyczno-językowa. Towarzyszące jej zróżnicowanie warunków realizacji sprawia, że przestępstwa te nie poddaja się rozłącznym kwalifikacjom. Wydaje się, iż przez wzgląd na tę rozmaitość zasadne jest tworzenie ich nierozłącznych i niewyczerpujacych typologii przy świadomości faktu, że niemal w każde $z$ nich wpisane sa elementy odpowiadające co najmniej dwóm typom. Wstępne, autorskie typologie przestępstw $z$ milczenia zostaną przedstawione poniżej.

Przestępstwa $z$ milczenia podzielić można na wyłączne i niewyłączne. Wyłączne przestępstwa $z$ milczenia określone zostały przez ustawodawcę w ten sposób, że ich popełnienie możliwe jest wyłącznie poprzez powstrzymanie się od użycia języka rozumianego jako czyn. W wypadku natomiast niewyłącznych przestępstw $z$ milczenia samo milczenie jest jedną $z$ kilku przewidzianych, równoważnych pod względem sankcji karnych czynności wykonawczych. Powołać warto w tym miejscu przykład przestępstwa zaniechania obywatelskiej denuncjacji jako przestępstwa wyłącznego oraz przestępstwa składania fałszywych zeznań jako przestępstwa niewyłącznego, którego czynność wykonawcza określona została przez ustawodawcę w formie koniunkcji - milczenia lub wypowiedzi:

Kto, mając wiarygodna wiadomość o karalnym przygotowaniu albo usiłowaniu lub dokonaniu czynu zabronionego określonego w art. 118, art. 118a, art. 120-124, art. 127 , art. 128, art. 130, art. 134, art. 140, art. 148, art. 156, art. 163, art. 166, art. 189, art. $197 \S 3$ lub 4, art. 198, art. 200, art. 252 lub przestępstwa o charakterze terrorystycznym, nie zawiadamia niezwłocznie organu powołanego do ścigania przestępstw, podlega karze pozbawienia wolności do lat $3 .^{7}$

Kto, składając zeznanie mające służyć za dowód w postępowaniu sądowym lub $\mathrm{w}$ innym postępowaniu prowadzonym na podstawie ustawy, zeznaje nieprawdę lub zataja prawdę, podlega karze pozbawienia wolności od 6 miesięcy do lat $8 .{ }^{8}$

7 Art. 240 par. 1 ustawy z dnia 6 czerwca 1997 roku Kodeks karny, Dz. U. $\mathrm{Nr}$ 88, poz. 553 z późniejszymi zmianami.

8 Art. 233 par. 1 ustawy z dnia 6 czerwca 1997 roku Kodeks karny, Dz. U. Nr 88, poz. 553 z późniejszymi zmianami. 
Przestępstwo składania fałszywych zeznań może zatem zostać w przeciwieństwie do przestępstwa zaniechania denuncjacji - popełnione nie tylko poprzez powstrzymanie się od użycia języka, ale także poprzez jego użycie i formułowanie wypowiedzi niezgodnych $z$ obiektywnym stanem rzeczy. Możliwe jest także dopuszczenie się go częściowo poprzez mówienie, a częściowo poprzez milczenie [Filar i in. 2016].

Przestępstwa $z$ milczenia podzielić można ponadto na przestępstwa bezpośrednie i pośrednie. Wyróżnikiem jest w tym wypadku fakt, czy ustawodawca wprost przewidział powstrzymanie się od użycia języka jako formę wykonawcza czynu, oczywiście przy zachowaniu innych wymaganych warunków fortunności. W wypadku przestępstw bezpośrednich milczenie zostało nazwane w ustawie za pomocą słów je oznaczających, a w wypadku przestępstw pośrednich milczenie stanowi jedynie dorozumianą formę realizacji czynu. Dla jasności wskażmy przykłady:

Kto, oddając usługi wywiadowcze Rzeczypospolitej Polskiej, wprowadza w błąd polski
organ państwowy przez dostarczanie podrobionych lub przerobionych dokumentów
lub innych przedmiotów albo przez ukrywanie prawdziwych lub udzielanie fałszy-
wych wiadomości mających istotne znaczenie dla Rzeczypospolitej Polskiej, podlega
karze pozbawienia wolności od roku do lat $10 .{ }^{9}$

Kto publicznie znieważa Prezydenta Rzeczypospolitej Polskiej, podlega karze pozbawienia wolności do lat $3 .{ }^{10}$

W wypadku przestępstwa penalizowanego w art. 132 Kodeksu karnego milczenie jest jedna $z$ form wykonawczych wskazanych wprost $\mathrm{w}$ treści przepisu ustawowego; w wypadku natomiast przestępstwa penalizowanego w art. 135 par. 2 Kodeksu karnego czynność wykonawcza określona została przez ustawodawcę zbiorczo - poprzez sformułowanie znieważa. Można zakładać, że znieważenie Prezydenta Rzeczypospolitej Polskiej zostałoby dokonane właśnie poprzez powstrzymanie się od użycia języka wówczas, gdy jego użycia wymagaja zasady protokołu (na przykład milczace ignorowanie Prezydenta i nieodpowiadanie na jego pytania). Jak wskazał Sąd Najwyższy,

przestępstwo znieważenia sprowadza się do tych zachowań sprawcy, które wyrażają pogardę dla innej osoby, w szczególności maja poniżyć ją, uwłaczać godności oraz sprawić, aby poczuła się obrażona. ${ }^{11}$

9 Art. 132 ustawy z dnia 6 czerwca 1997 roku Kodeks karny, Dz. U. Nr 88, poz. 553 z późniejszymi zmianami.

10 Art. 135 par. 2 ustawy $z$ dnia 6 czerwca 1997 roku Kodeks karny, Dz. U. $\mathrm{Nr}$ 88, poz. 553 z późniejszymi zmianami.

11 Postanowienie Sadu Najwyższego z dnia 7 maja 2008 r., sygn. akt. III KK $234 / 07$. 
W zakresie tego pojęcia mieszczą się różnorodne zachowania sprawcy, niezależnie od ich formy (gesty, wypowiedzi, a także milczenie).

Ostatnia proponowana typologia przestępstw $z$ milczenia jest typologia uwzględniająca przestępstwa popełniane poprzez milczenie w opozycji do języka mówionego oraz przestępstwa popełnianie w opozycji do języka pisanego. Te pierwsze określić można mianem przestępstw z milczenia sensu stricto, drugie zaś - przestępstw z milczenia sensu largo. Wyróżnikiem jest tutaj forma, w jakiej najpewniej zostałaby skonstruowana wypowiedź w sytuacji, gdyby sprawca nie zdecydował się wkroczyć na przestępcza drogę (forma ustna albo pisemna). Przestępstwa $z$ milczenia sensu largo polegają najczęściej na niewypełnieniu wymaganych prawem dokumentów bądź nieprzekazaniu ich do kompetentnych organów, które to elementy składaja się na ogół warunków fortunności przewidzianych przez ustawodawcę. Wielu badaczy podkreśla, że wypowiedzi pisemne na równi $z$ wypowiedziami ustnymi maja przy spełnieniu wymaganych warunków fortunności charakter performatywny [por. Pieprzyca 2016; Kowalczyk 2020]. Przykładem przestępstwa $z$ milczenia sensu stricto niech będzie przywołane już powyżej przestępstwo zaniechania denuncjacji, która przeważnie przybiera formę zeznań składanych osobiście przed organami ścigania, ewentualnie przyjmuje postać anonimowego zawiadomienia telefonicznego czy listowego. Przykłady przestępstw $z$ milczenia sensu largo to natomiast wybrane przestępstwa przeciwko prawom osób wykonujacych pracę zarobkową:

Kto narusza przepisy prawa o ubezpieczeniach społecznych, nie zgłaszając, nawet za zgoda zainteresowanego, wymaganych danych albo zgłaszajacc nieprawdziwe dane mające wpływ na prawo do świadczeń albo ich wysokość, podlega grzywnie, karze ograniczenia wolności albo pozbawienia wolności do lat $2 .{ }^{12}$

Kto wbrew obowiąkkowi nie zawiadamia w terminie właściwego organu o wypadku przy pracy lub chorobie zawodowej albo nie sporządza lub nie przedstawia wymaganej dokumentacji, podlega grzywnie do 180 stawek dziennych albo karze ograniczenia wolności. ${ }^{13}$

Jak zostało już podkreślone, podział na przestępstwa $z$ milczenia sensu stricto i sensu largo nie jest rozłączny, bowiem można sobie wyobrazić zarówno wypowiedź denuncjacyjna w postaci pisemnej, jak i ustne zawiadomienie organu pracowniczego. Podział ten dokonywany jest przy uwzględnieniu formy, która dla wyżej wymienionych przestępstw przyjmowana jest przeważnie w praktyce wykonywania prawa.

12 Art. 219 ustawy z dnia 6 czerwca 1997 roku Kodeks karny, Dz. U. Nr 88, poz. 553 z późniejszymi zmianami.

13 Art. 221 ustawy z dnia 6 czerwca 1997 roku Kodeks karny, Dz. U. Nr 88, poz. 553 z późniejszymi zmianami. 


\section{WNIOSKI}

W toku prowadzonych analiz jednoznacznie wykazano, że na gruncie polskiego prawa karnego milczenie traktowane jest jako autonomiczny czyn przestępczy, który - podobnie jak przestępcze wypowiedzi - rodzi negatywne skutki prawne dla sprawców. Skutki te przesadzają o performatywnym charakterze milczenia, $z$ którego zaistnieniem wiąże się zmiana rzeczywistości prawnokarnej - nierzadko nie tylko dla samego sprawcy, ale również dla osoby pokrzywdzonej, na rzecz której orzeczone moga zostać w wyroku właściwe środki naprawcze (nawiązka, obowiazek naprawienia szkody etc.).

Przestępstwa $z$ milczenia są równoważne przestępstwom werbalnym, jak również przestępstwom nielingwistycznym. Podlegają takiemu samemu katalogowi kar, a także takim samym zasadom przypisania winy sprawcy. W świetle prawa karnego sa zatem pełnowartościowymi, choć niezwerbalizowanymi aktami mowy - aktami performatywnymi.

$\mathrm{W}$ niniejszym artykule analiza materiału ustawowego ograniczona została do Kodeksu karnego, jednak bez watpienia badania warto rozszerzyć o kolejne prawnokarne ustawy funkcjonujace w Polsce. Badania moga mieć istotne znaczenie dla juryslingwistyki, stanowiącej naukę hybrydowa, funkcjonujacca na styku językoznawstwa i prawoznawstwa. Maja również fundamentalne znaczenie społeczne poprzez uświadamianie obywatelom, że sa sytuacje, w których powstrzymanie się od użycia języka rodzi odpowiedzialność karną.

\section{Bibliografia}

J.L. Austin, 1962, How to do things with words, Oxford.

J.L. Austin, 1993, Mówienie i poznawanie, tłum. B. Chwedeńczuk, Warszawa.

M. Bańko (red.), 2007, Słownik języka polskiego, t. I, Warszawa.

J. Bartmiński, 2012, Językowe podstawy obrazu świata, Lublin.

P. Dobosz, 2011, Milczenie i bezczynność w prawie administracyjnym, Kraków.

M. Filar (red.), 2016, Kodeks karny. Komentarz, Warszawa.

J. Kowalczyk, 2020, Milczenie jako specyficzna forma komunikatu $w$ dyskursie prawnym, „Respectus Philologicus” vol. 37, s. 104-133.

P. Pieprzyca, 2016, Akt notarialny jako wypowiedź performatywna, „Comparative Legilinguistics" vol. 25, s. 27-40.

R.A. Stefański (red.), 2020, Kodeks karny. Komentarz, Warszawa.

D. Świecki (red.), 2020, Kodeks postępowania karnego. Komentarz, t. I, II, Warszawa.

J. Warylewski, 2020, Prawo karne. Część ogólna, Warszawa.

M. Załucki (red.), 2020, Kodeks cywilny. Komentarz, Warszawa.

M. Zubik, 2020, Prawo konstytucyjne współczesnej Polski, Warszawa. 


\section{Silence as a performative criminal act on the example of the Polish Criminal Code}

\section{Summary}

In the paper, the theory of John L. Austin's speech acts is juxtaposed with the theory of crime functioning in the Polish criminal law science. The aim of the study was to answer the question whether silence in the light of criminal law can be understood as equivalent to an act of speech, which is at the same time a criminal act, and therefore has negative legal consequences for the perpetrator. The definition of the framework for the criminal law performativity of silence was based on an analysis of a fundamental act of criminal law in Poland - the Criminal Code of 1997. Then an attempt was made to create a typology of crimes of silence penalised in this Code. The paper emphasises the role of silence as a fully autonomous executive form of crimes, and thus its importance from the perspective of the society and the state.

Keywords: silence - crime - criminal code - act of speech - performativity

Adj. Monika Czarnecka 